\title{
RELATIONSHIP BETWEEN TIDAL FORESTS (MANGROVES) AND COMMERCIAL SHRIMP PRODUCTION IN INDONESIA
}

\author{
by \\ PURWITO MARTOSUBROTO ${ }^{2)}$ and NURZALi NAAMIN ${ }^{1)}$
}

\begin{abstract}
An attempt has been made to relate the surface areas of tidal forest (mangrove) and the commercial shrimp production in those areas and adjacent waters in Indonesia. A significant linear relationship ( $\alpha=0.01$ ) was obtained between these two variables as expressed in an equation : $\mathrm{Y}=$ $5.473+0.1128 \mathrm{X}$, where $\mathrm{Y} k$ the shrimp production in $10^{3}$ tons and $\mathrm{X}$ is the mangrove surface area in $10^{4} \mathrm{Ha}$. This relationship indicates that the shrimp production increases with the size of the tidal forest area implying that any reduction of the tidal forests, e.g. for industrial and agricultural purposes will cause a decrease in shrimp yield.
\end{abstract}

\section{INTRODUCTION}

Indonesia has a long belt of tidal forests (mangroves) which extends from Sumatra in the western part of the Archipelago to Irian Jaya in the eastern part. Most of these areas have not been touched by human activities except those in the north coast of Java where many have been converted into brackish water ponds for milkfish culture.

The use of mangroves themselves by people has been limited for charcoal and tannin production. The fact that mangrove areas play an important role in fisheries especially in shrimp fisheries has been well documented (HEALD \& ODUM 1969, MACNAE 1974). In Indonesia most of the penaeid shrimps are mangrove dependent (MACNAE 1974, UNAR 1972). These shrimps spawn offshore, the newly hatched larvae drifted with the current to inshore areas often bordered with mangroves where they stay until they reach juvenile stages and migrate offshore. NAAMIN \& SUDRADJAT (1973) have found a large proportion of mature females of Penaeus merguiensis in Cilacap (Southern Java Coast) offshore waters, while MARTOSUBROTO \& SUDRADJAT (1973) have encountered a high concentration of penaeid larvae in the plankton samples collected from the Cilacap mangrove areas in the vicinity of Segara Anakan lagoon. There, the fishermen also collect juvenile shrimps with tidal traps.

Shrimp abundance in offshore waters is among other things dependent on recruitment from the juveniles inshore grounds. This is the reason why

1) Marine Fisheries Research Institute, Jl. Krapu 12, Jakarta Barat, Indonesia. 
PURWITO MARTOSUbRoto \& NURzali NAAMIN

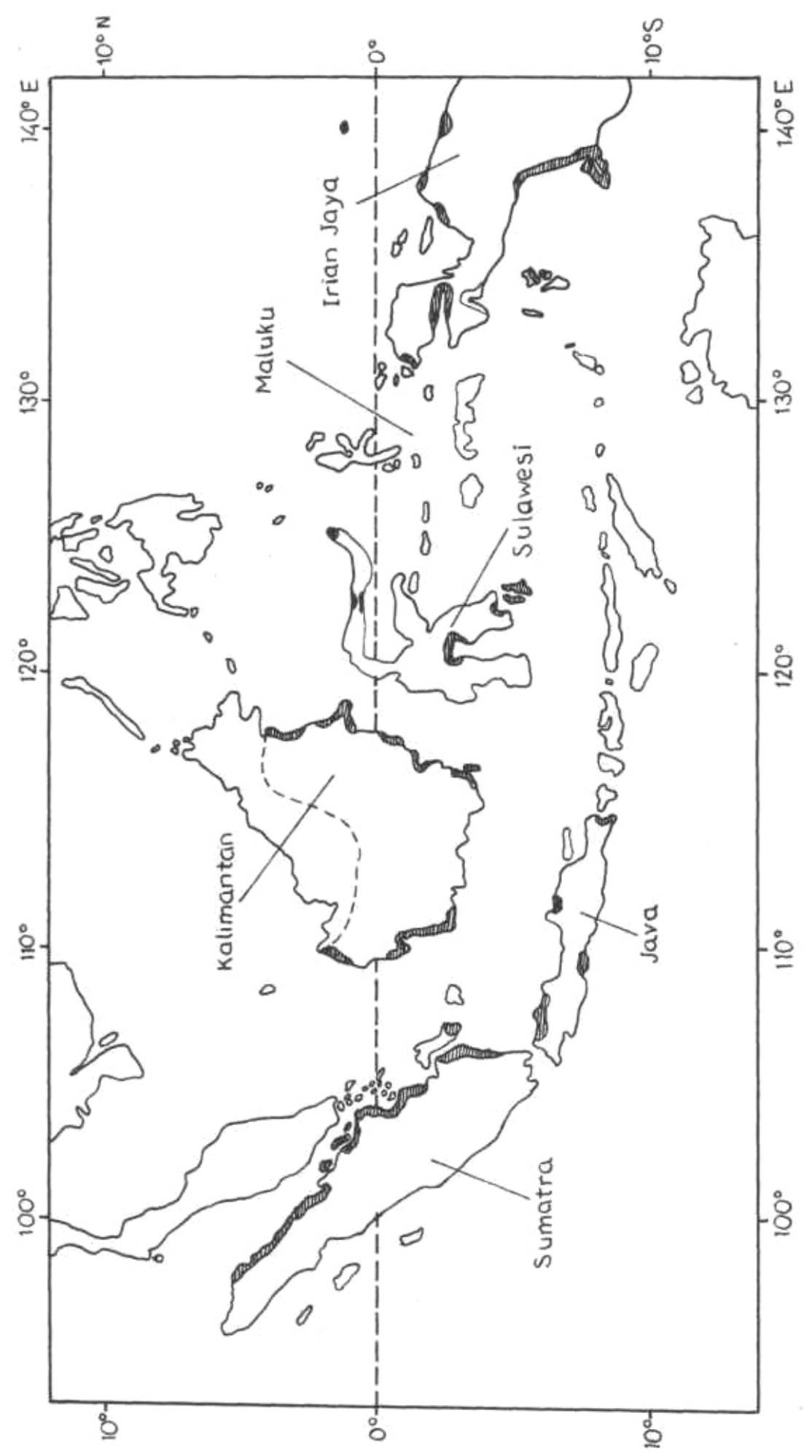

Figure 1. Distribution of mangrove in Indonesia (not to scale) 
mangrove area as the shrimp nursery ground has become one of the limiting factors for shrimp abundance in offshore waters.

The aim of this paper is to examine the character of the relationship between shrimp production offshore and mangroves in Indonesia. Such relationship should be taken into account by anyone involved in the management of mangroves.

\section{SOURCES AND TREATMENT OF DATA}

Surface area of the tidal forest was obtained by planimetry from the latest available map (1950) kindly provided by the Directorate of Planning, Directorate General of Forestry in Bogor. The map has a scale of 1 : 2,500,000 except for Java $1: 1,000,000$ and no corrections have been made since.

Shrimp production figures (Table I) from the provinces were derived from the Fisheries Statistics of Indonesia (ANONYMOUS 1973). The data for Irian Jaya were obtained from the catch records of Fishing Companies operating in the region (NAAMIN \& SUDRADJAT, in press). The data for Cilacap Shrimp Fisheries on the south coast of Java were obtained in a joint study of this fishery by the FAO/UNDP Fisheries Development and Management Project and the Indonesian Marine Fisheries Research Institute (VAN ZALINGE \& NAAMIN, in press). AH weights in Table I are expressed "head on". Figure 1 shows schematically the distribution of mangroves in Indonesia.

Shrimp production from some provinces were pooled when shrimp landings overlapped e.g. in the case of North Sumatra and Aceh Provinces, both in the Malacca Strait. In such cases the respective mangrove areas were also pooled. The result of these groupings is shown in Table I.

\section{RESULT AND DISCUSSION}

There is a highly significant linear relationship ( $\alpha=0.01$ ) between shrimp production and size of mangrove area. This relationship is expressed by the equation :

$$
\mathrm{Y}=5.473+0.1128 \mathrm{X}
$$

with a significant correlation coefficient $r=0.89$ (Fig. 2). The fact that some penaeid shrimps which are not depending on mangroves such as Penaeus semisulcatus and some of the genus Parapenaeopsis (MACNAE 1974), as well 
PURWITO MARTOSUBROTO \& NURZALI NAAMIN

Table I. Mangrove area and shrimp production

\begin{tabular}{|c|c|c|c|c|c|}
\hline \multirow{2}{*}{$\begin{array}{l}\text { Area/Province } \\
\text { SUMATRA: } \\
\text { Aceh }\end{array}$} & \multicolumn{2}{|c|}{$\begin{array}{c}\text { Mangrove area } \\
\text { (ha) }\end{array}$} & \multicolumn{3}{|c|}{$\begin{array}{c}\text { Shrimp production } \\
\text { (ton) }\end{array}$} \\
\hline & $\begin{array}{r}48,125 \quad) \\
\end{array}$ & $129,375^{1)}$ & 1,643 & $\begin{array}{l}\text { ) } \\
\text { ) }\end{array}$ & $\mathbf{9 , 5 7 2}$ \\
\hline Riau & $343,750 \quad)$ & & 11,875 & ) & \\
\hline Jambi & $67,500)$ & $525,625^{2)}$ & 1,138 & ) & 14,882 \\
\hline South Sumatra & 102,500 ) & & 710 & ) & \\
\hline
\end{tabular}

JAVA :

North \& east

$58,700^{3)}$

$5,214^{+)}$

coast

South coast

$26,250^{4)}$

$4,308^{++)}$

KALIMANTAN :

West \& Central

Kalimantan South

Kalimantan

$181,250 \quad$ )

7,457 )

East Kalimantan

$68,125) 696,875^{5}$

447,500 )

1,805 )

2,675 )

SULAWESI:

North Sulawesi

37,500 ) $96,250^{6)}$

$398 \quad 5,243$

South Sulawesi

$\mathbf{5 8 , 7 5 0}$ )

4,845 )

MALUKU:

A r u

70,625

$4,642 \quad)$

IRIAN JAVA :

Irian Jaya

898,125

$968,750^{7)}$

$10,765)$

Remarks:

- The table shows the groupings used in the regression analysis [No. 1), 2), 5), 6), 7)]

- Data on shrimp production were obtained from the Fisheries Statistics of Indonesia 1973, except those marked with :

+) from the Provincial Fisheries Report of Jakarta 1973 and the Fisheries Statistics of Indonesia 1973

++ ) from the Provincial Fisheries Report of West Java and Van Zalinge \& Naamin (in press)

++ from Naamin and Sudradjat (in press). 


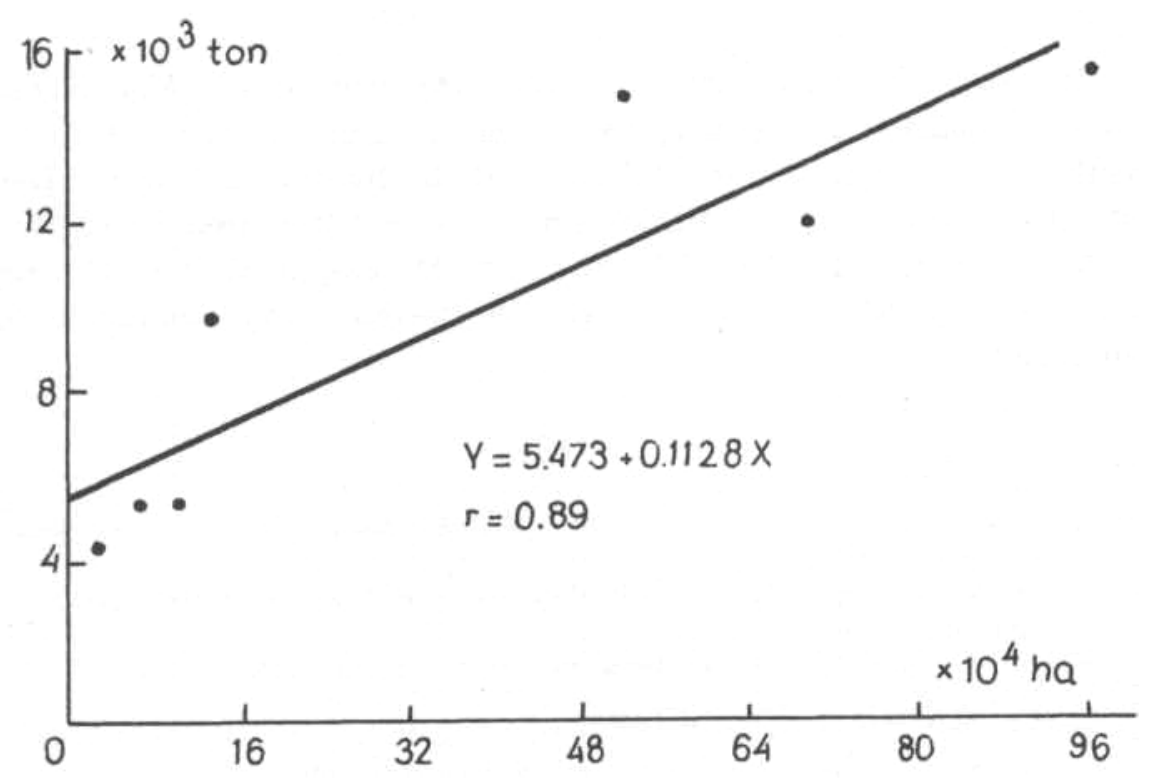

Figure 2. Relationship between mangrove area ( $10^{4}$ ha) and shrimp production $\left(10^{3}\right.$ ton $)$.

as non-penaeid shrimps such as mysids, were included in some of the landing statistics explains the high value of intercept $(\mathrm{a}=5.473)$ in the relationship. SUJASTANI (personal communication) has noticed that a large number of mysids, locally known as "rebon" were reported as shrimp in the Malacca Strait landing places. The relationship nevertheless shows that the production of shrimp increases with the size of mangrove area. This means that any clearing of mangrove is likely to reduce the shrimp production as a whole. This is the reason why the planned reclamation project in the mangroves area of Segara Anakan on south coast of Java has become a matter of great concern among the ecologists in Indonesia and has caused several scientists and scientific institutions to study and assess the value of mangrove. A study by the Faculty of Biology of the University of Gajahmada in Jogyakarta on the mangrove ecosystem in Cilacap is still underway. TURNER (1975) made an assessment on the possible effect of this reclamation project and stated in his summary : "the project impact will be to decrease offshore landing of estuarine dependent shrimp proportionally to the degree of which the local areas of mangrove are destroyed. Fish catches will also decline in a parallel manner. The impact on Java's and Indonesia's export earnings will be large because of the high price of shrimpmost of which are exported". 


\section{PURWITO MARTOSUBROTO \& NURZALI NAAMIN}

\section{ACKNOWLEDGEMENTS}

We wish to thank Mr. M. UnAR, Director of the Marine Fisheries Research Institute in Jakarta, for his encouragement to write this paper. Thanks are also due to Mr. D.PAULY of the Indonesian-German Demersal Fisheries Project, for discussions on the ideas presented here. Mr. VAN ZALINGE of the FAO/UNDP Fisheries Development and Management Project kindly provided with useful suggestions and comments on the manuscript.

\section{REFERENCES}

Anonymous 1973a. Laporan tahunan Dinas Perikanan Daerah Tingkat II Jawa Barat. 70 pp. (Unpublished Annual Report).

1973b. Laporan tahunan Dinas Perikanan Daerah Khusus Ibukota Jakarta. 52 pp (Unpublished annual report).

----------- 1973c. $\quad$ Statistik Perikanan. Direktorat Jendral Perikanan, Departemen Pertanian No. 3/ 1974, : 68 pp.

MACNAE, W. 1974. Mangrove forests and fisheries. FAO/UNDP Indian Ocean Fishery Programme. Indian Ocean Fishery Commision. IOFC/DEV/74/34 : $35 \mathrm{pp}$.

Martosubroto, P. and A. Sudradjat 1973. Mempelajari beberapa segi ekologi dan Perikanan di Segara Anakan. Publ Mar. Fish. Inst. (LPPL) 1/73: 73 - 84.

NAAMIN, N. and A. SUDRAJAT 1973. Perkembangan trawl Udang di pantai Selatan Jawa. Publ. Mar. Fish. Res. Inst. (LPPL) 1/73: $34-55$.

- 1976. Progress report of the Arafura shrimp fishery. Publ. Mar. Res. Inst. (LPPL) 2/75 - PL. 056/75.

TURner, RE. 1975. The Segara Anakan Reclamation Project. The impact on commercial fisheries. A report to Engineering Consultant, Inc. Denver, Colorado : 71 pp.

UNAR, M. 1972. Review of the Indonesian shrimp fishery and its present development. Publ. Mar. Fish. Inst. (LPPL) $1 / 72: 1-26$

VAn Zalinge, N and N. NAAmin (in press). Cilacap based trawler fishery for shrimp along south coast of Jawa. Publ. Mar. Fish. Inst. 